\title{
Effect of Lavender Powder on Microbial, Physicochemical, Sensory and Functional Properties of Yoghurt
}

\author{
Hale İnci ÖZTÜRK ${ }^{1}$, Sümeyye AYDIN *1, Nihat AKIN ${ }^{1}$
}

${ }^{1}$ Department of Food Engineering, University of Selcuk, Faculty of Agriculture, Konya, Turkey

Received: 05 May 2017 - Revised: 04 July 2017 - Accepted: 26 July 2017

\begin{abstract}
The objective of this research was to determine changes in microbial flora and functional properties of yoghurts containing lavender powder at rates of $0.010,0.025,0.050$ and $0.075 \%$. The effect of lavender powder on the potential flora during fermentation was determined, furthermore, alterations in microbiological properties of yoghurts were examined during the storage period (1 d, $7 \mathrm{~d}$ and $14 \mathrm{~d}$ ). Yoghurt samples containing 0.010, 0.025, 0.050 and $0.075 \%$ lavender powder, were coded A1, A2, A3, and A4, respectively. Streptococcal counts were $8.89 \pm 0.21,8.71 \pm 0.09,8.77 \pm 0.13,8.66 \pm 0.04$ and $8.91 \pm 0.13 \log \mathrm{CFU} / \mathrm{g}$, respectively, in the control, A1, A2, A3, and A4 samples. No decrease in streptococcal counts was observed during storage in all samples. Lactobacilli counts were $8.58 \pm 0.06,8.43 \pm 0.26,8.34 \pm 0.26,8.02 \pm 0.02$ and $8.53 \pm 0.34 \log$ CFU/g, respectively, in the control, A1, A2, A3 and A4 samples. While the lactobacilli count of the control sample decreased during the storage period, it remained constant in A1, A2, A3 and A4 samples at the end of the storage time. It was determined that the lavender powder supplementation contributed the viability of lactobacilli during storage. No statistically significant difference was found in the total bacterial counts between the samples on the first day, however the highest total bacteria content was determined in A4 sample $(8.31 \pm 0.01 \log \mathrm{CFU} / \mathrm{g})$ at the end of the storage period $(14 \mathrm{~d})$.
\end{abstract}

Keywords: antioxidant effect, lavender, microbial potential, yoghurt

\section{INTRODUCTION}

Yoghurt is a fermented milk product that is produced by Streptococcus thermophilus ( $S$. thermophilus) and Lactobacillus delbrueckii ssp. bulgaricus (L. bulgaricus) and consumed all around the world [1]. Yoghurt fortification has an important role to develop nutritional, sensorial, functional and health promoting effects of the yoghurt [2]. In this context, vegetables $[3,4]$, fruits [5, 6], fibers $[7,8]$, seed extracts [9] and plants [10, 11] have been used in yoghurt production.

Lavandula officinalis L. is a fragrant herb belonging to Lamiaceae family and called lavender [12]. It is known as having therapeutic and antimicrobial effects [13]. It was reported that lavender showed high antioxidant properties [14]. Lavender is rich with phenolic contents and ferulic acid is the major phenolic compound of it [15].

\section{${ }^{*}$ Corresponding Author E-mail: smyaydin@yahoo.com}


In this study, the effect of lavender powder used at different ratios on potential yoghurt bacteria was investigated. For this purpose, 0.010, 0.025, 0.050 and $0.075 \%$ lavender powders were added to yoghurt samples. The effect of lavender powder on the kinetic parameters of acidification during fermentation was examined, furthermore, changes in microbial growth were monitored during the storage period $(1 \mathrm{~d}, 7 \mathrm{~d}$ and $14 \mathrm{~d})$. The antioxidant activities and total phenolic contents of yoghurt samples were investigated. Yoghurt samples were subjected to sensory testing to determine consumer acceptance.

\section{MATERIAL and METHODS}

\subsection{Materials}

Medium-heat skim milk powder $(34.5 \%$ protein, $3.5 \%$ moisture, $7.2 \%$ ash, $55 \%$ lactose, pH:6.55, \% titratable acidity 0.112) were obtained from ENKA Dairy Co. Ltd. (Konya, Turkey). Milk was ensured farm of Selcuk University dairy farm. YF-L901 consisting of S. thermophilus and $L$. bulgaricus were used as starter cultures in yoghurt production and they were supplied from Chr's Hansen-Peyma (Istanbul). Harvested lavender plants (June-July) were dried for 1 month at room temperature in light-free environment and then powdered with blender.

\subsection{Production of Set-Type Yoghurt and Sample Design}

Five yoghurt formulations were performed by described by Akın [1]. A1, A2, A3 and A4 samples contained lavender powder at $0.010,0.025,0.050$, and $0.075 \%$, respectively, whereas no lavender powder was added to control sample. All yoghurt formulations were standardized to $16 \%$ dry matter content by milk powder. In A1, A2, A3 and A4 samples, milk powder and lavender powder were mixed with fresh cow milk, while only milk powder was added to fresh cow milk in control sample. Afterwards the mixes were pasteurized at $85{ }^{\circ} \mathrm{C}$ for $10 \mathrm{~min}$ and cooled $42{ }^{\circ} \mathrm{C}$. The yoghurt mixes were inoculated with $2 \%(\mathrm{w} / \mathrm{v})$ starter culture and then distributed in $150 \mathrm{~mL}$ sterile plastic containers and incubated at $42{ }^{\circ} \mathrm{C}$ until a pH was reached to 4.6. Yoghurt samples were stored in a refrigerator $\left(4{ }^{\circ} \mathrm{C}\right)$. during storage time $(1 \mathrm{~d}, 7 \mathrm{~d}$, and $14 \mathrm{~d})$. Yoghurt samples were manufactured each in 2 replications.

\subsection{Monitoring of Fermentation Kinetics}

The changes in $\mathrm{pH}$ and titratable acidity during the fermentation were monitored until the $\mathrm{pH}$ 4.6. Maximum acidification rate $\left(\mathrm{V}_{\max }\right)$, the time to reach the maximum acidification rate $\left(\mathrm{T}_{\max }\right)$ and the time at which was the end of the fermentation $\left(\mathrm{T}_{\mathrm{e}}\right)$ were determined.

\subsection{Physicochemical Analysis}

Fat [16], water holding capacity [17], syneresis [18], and color [19] were done on day 7 , $\mathrm{pH}$ and titratable acidity [20] were monitored during the storage period.

\subsection{Assessment of Antioxidant Activity}

Antioxidant activity was determined by two different radical scavenging methods on day 7. ABTS [21] and DPPH [22] radical scavenging methods were used due to differences in susceptibility of the methods. ABTS radical scavenging activity results were explicated in terms of Trolox equivalent antioxidant capacity (TEAC) value, while DPPH radical scavenging results were reported as \% inhibition.

\subsection{Total Phenolic Content}

The total phenolic compounds in yoghurts were determined by using the method of McCue and Shetty [23] on day 7. The results that were calculated based on the gallic acid curve were given as milligram gallic acid equivalents (GAE) per gram of yoghurt samples. 


\subsection{Determination of Changes in Microbial Flora During Storage Time}

S. thermophilus and L. bulgaricus counts of yoghurt samples were determined during the storage time. S. thermophilus colonies were enumerated in M17 agar under aerobic incubation at $37{ }^{\circ} \mathrm{C}$ for $24-48 \mathrm{~h}$ [24], while L. bulgaricus colonies were counted in MRS agar under anaerobic incubation at $45^{\circ} \mathrm{C}$ for 24-48 h [25]. Potato Dextrose Agar was used to determine yeast and fungi under aerobic incubation at $25{ }^{\circ} \mathrm{C}$ for $5 \mathrm{~d}$ [20]. Total bacteria were enumerated in Plate Count Agar (PCA) at $30^{\circ} \mathrm{C}$ for $48 \mathrm{~h}$ [26].

\subsection{Sensory Analysis}

Sensorial tests of yoghurt samples were evaluated by a panel of seven members using seven-point hedonic scale [27] (1: strongly disliked; 7: strongly liked). Panelists appraised the appearance, taste and flavor, smell, texture, acidity and general acceptability. Sensory evaluation was done on the 7 th day of storage time.

\subsection{Statistical Analysis}

The parameters of experimental yoghurts were assessed by General Linear Model ANOVA by MiniTab 7.1 [28]. Different groups were compared by the Tukey test at $\mathrm{P}<0.05$, and statistically significant differences among them were indicated by different letters.

\section{RESULTS and DISCUSSIONS}

\subsection{Fermentation Kinetics}

The fermentation kinetic of each sample group was obtained by calculating the maximum acidification rate $\left(V_{\max }\right)$, the time to reach $V_{\max }\left(\mathrm{T}_{\max }\right)$ and the time required to reach the end of fermentation $\left(\mathrm{T}_{\mathrm{pH} 4.6}\right) . \mathrm{V}_{\max }, \mathrm{T}_{\max }$ and $\mathrm{T}_{\mathrm{pH} 4.6}$ values are given in Table 1 and the changes in the $\mathrm{pH}$ and titratable acidity values occurring throughout fermentation are shown in Figure 1.

Table 1. Acidification kinetics of yoghurt samples during fermentation.

\begin{tabular}{lccc}
\hline Samples & $\begin{array}{c}\mathrm{V}_{\max } \\
\left(10^{-3} \mathrm{pH} \text { units } \min ^{-1}\right)\end{array}$ & $\begin{array}{c}\mathrm{T}_{\max } \\
(\mathrm{h})\end{array}$ & $\begin{array}{c}\mathrm{T}_{\mathrm{pH} 4.6} \\
(\mathrm{~h})\end{array}$ \\
\hline Control & $11.00 \pm 0.00^{\mathrm{a}}$ & $2.75 \pm 0.01^{\mathrm{ns}}$ & $6.16 \pm 0.02^{\mathrm{a}}$ \\
A1 & $10.12 \pm 0.01^{\mathrm{b}}$ & $2.25 \pm 0.00^{\mathrm{ns}}$ & $5.41 \pm 0.28^{\mathrm{b}}$ \\
A2 & $10.16 \pm 0.01^{\mathrm{b}}$ & $2.25 \pm 0.00^{\mathrm{ns}}$ & $5.33 \pm 0.22^{\mathrm{b}}$ \\
A3 & $9.16 \pm 0.02^{\mathrm{c}}$ & $2.75 \pm 0.01^{\mathrm{ns}}$ & $5.12 \pm 0.01^{\mathrm{b}}$ \\
A4 & $10.00 \pm 0.00^{\mathrm{b}}$ & $2.25 \pm 0.00^{\mathrm{ns}}$ & $5.37 \pm 0.17^{\mathrm{b}}$ \\
\hline
\end{tabular}

A1: with $0.010 \%$ lavender powder; A2: with 0.025\% lavender powder; A3: with 0.050\%; A4: with 0.075\% lavender powder. $\mathrm{V}_{\max }$ : maximum acidification rate; $\mathrm{T}_{\max }$ : time corresponding to $\mathrm{V}_{\max } ; \mathrm{T}_{\mathrm{pH} 4,6}$ : time to obtain $\mathrm{pH}$ 4.6. Different letters in the same column are significantly different $(\mathrm{P}<0.05)$; ns: not significant.

Statistically significant differences were observed in $\mathrm{V}_{\max }$ and $\mathrm{T}_{\mathrm{pH} 4.6 \text { values of the yoghurt }}$ samples $(\mathrm{P}<0.05)$. There was significant effect of lavender powder addition on $\mathrm{V}_{\max }$ (Table 1$)$. This effect may have been caused by components with buffering capacity such as phenolics present in the lavender [15]. Similar results were seen in the passion fruit peel added yoghurt [29]. There was no difference between the times to reach maximum acidification rates $\left(T_{\max }\right)$ of the samples. However, $\mathrm{T}_{\mathrm{pH} 4.6}$ was significantly reduced by adding lavender powder $(\mathrm{P}<0.05)$ and the highest decrease in $\mathrm{T}_{\mathrm{pH} 4.6}$ was observed in $\mathrm{A} 3$ sample.

Titratable acidity increased with time in all samples, but the highest increase occurred in the A3 and A4 samples. The formation of lactic acid advanced due to the increase in the amount of lavender powder. This may be due to the positive effect of lavender powder on lactic acid bacteria. De Martino and colleagues [30] reported that lavender oil exhibited no inhibitory activity against lactic acid bacteria. 


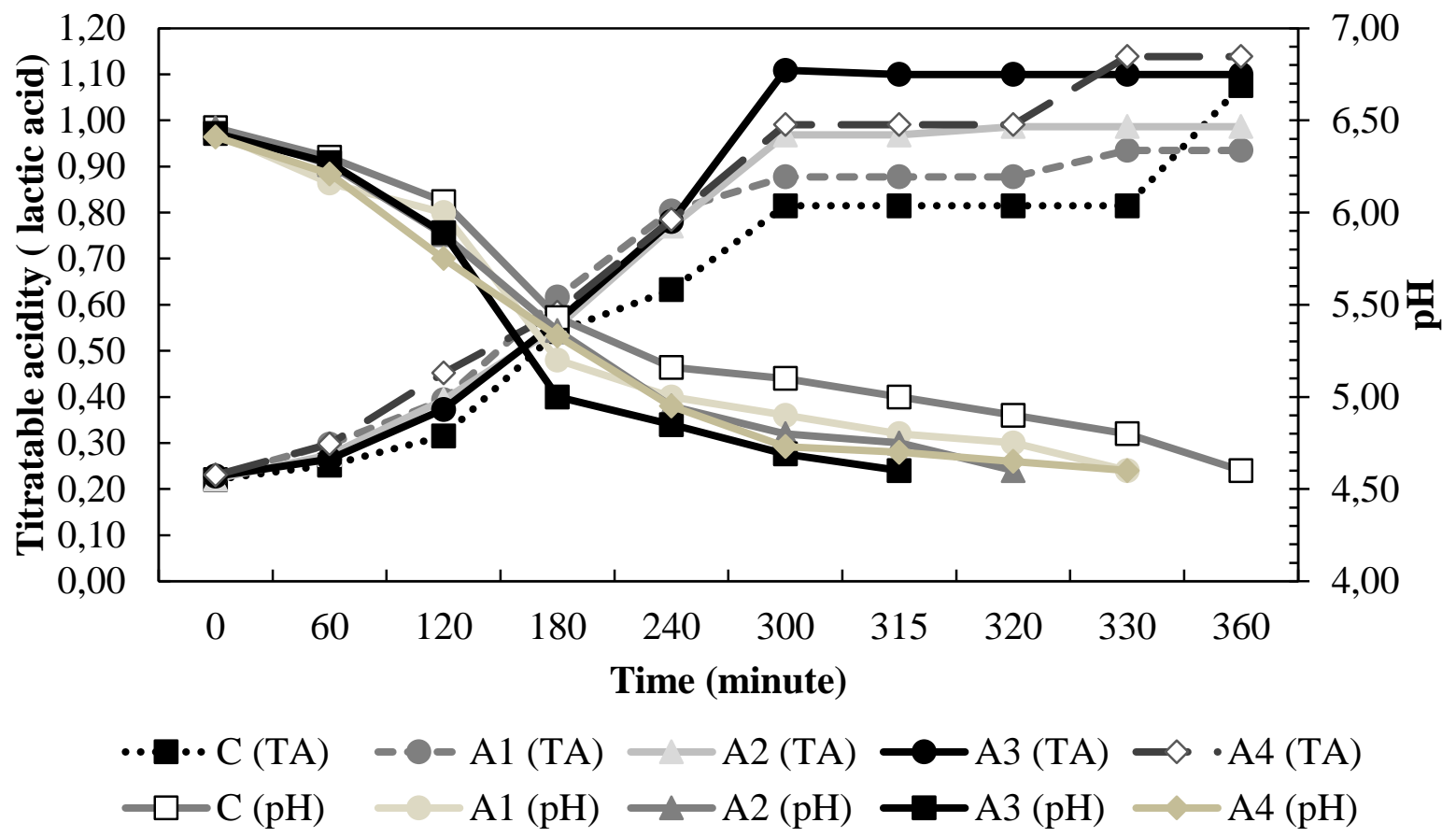

Figure 1. Changes in the $\mathrm{pH}$ and titratable acidity during fermentation. C: control; A1: with $0.010 \%$ lavender powder; A2: with $0.025 \%$ lavender powder; A3: with $0.050 \%$; A4: with $0.075 \%$ lavender powder.

\subsection{Physicochemical Characteristics of Yoghurt Samples}

Physicochemical properties of yoghurt samples are shown in Table 2. Water holding capacity and syneresis values of yoghurt samples were found between 56.55-61.20\%and 8.86$10.94 \%$, respectively and there were no statistical differences between the yoghurt samples (P>0.05). Fat values of samples were determined between $2.70-2.90 \%$, the differences in fat values were not statistically significant. While there were no statistical differences in the brightness and yellowness values of the yoghurt samples $(\mathrm{P}>0.05)$, the highest redness value was determined in the A4 sample $(\mathrm{P}<0.05)$.

Table 2. Some physicochemical properties, total phenolic contents and antioxidant activities of yoghurt samples (on day 7).

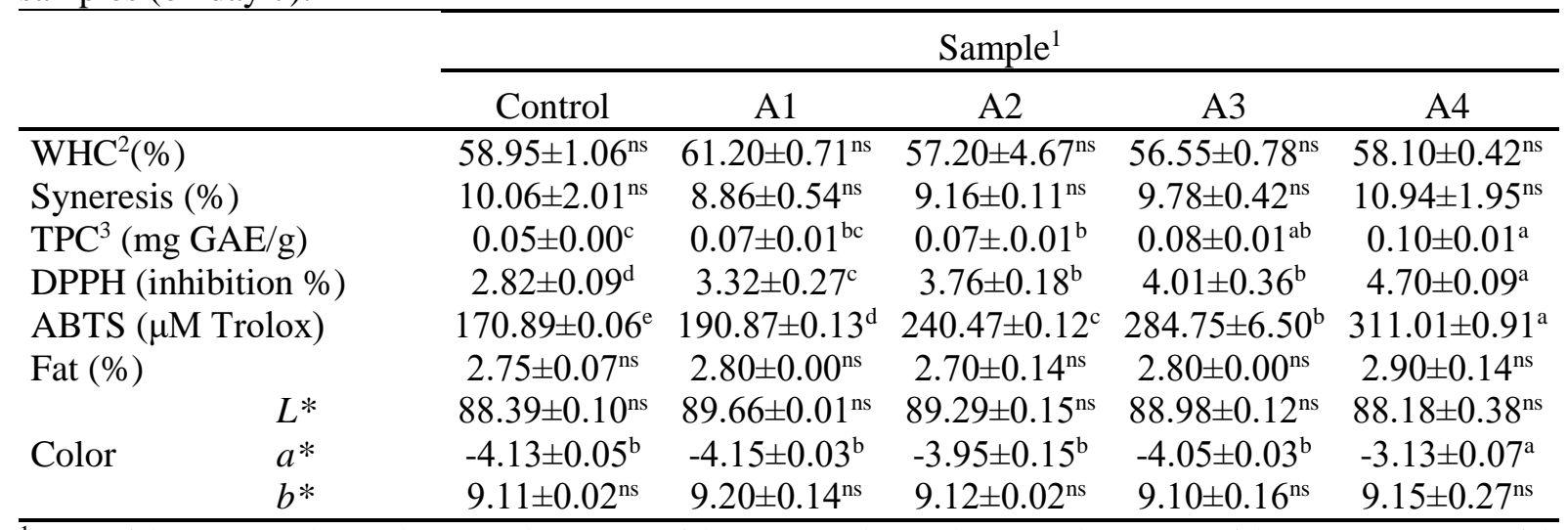

${ }^{1} \mathrm{~A} 1$ : with $0.010 \%$ lavender powder; A2: with $0.025 \%$ lavender powder; A3: with $0.050 \%$; A4: with $0.075 \%$ lavender powder. ${ }^{2} \mathrm{WHC}$ : Water holding capacity; ${ }^{3} \mathrm{TPC}$ : Total phenolic content. Values in same row having different superscripts differ significantly $(\mathrm{P}<0.05)$; ns: not significant. 
The $\mathrm{pH}$ and titratable acidity values monitored during storage time are given in Table 3 . After one day of cold storage the $\mathrm{pH}$ values of control, A1, A2, A3 and A4 samples were determined to be 4.48, 4.52, 4.58, 4.68, and 4.56, respectively. After 14 days of storage time, the $\mathrm{pH}$ values of all yoghurt samples decreased significantly $(\mathrm{P}<0.05)$ and the decrease in $\mathrm{pH}$ values were about $6.14-6.70 \%$. Titratable acidity values varied from 1.14 to $1.29 \mathrm{mg}$ lactic acid/g at the beginning of the storage. Titratable acidity of all samples increased by $11.40-$ $20.33 \%$ at the end of the cold storage. These results could be attributed to metabolic activities of microbial flora existed in yoghurt samples. Bonczar and colleagues [31] and Do Espírito and colleagues [29] reported that the increase in the titratable acidity values of yoghurts at the end of the 14 and 28 days was determined.

Table 3. Changes in $\mathrm{pH}$ and titratable acidity of yoghurt samples during the cold storage.

\begin{tabular}{ccccccc}
\hline \multirow{2}{*}{ Samples $^{1}$} & \multicolumn{3}{c}{$\mathrm{pH}$} & \multicolumn{3}{c}{ Titratable acidity (lactic acid\%) } \\
\cline { 2 - 7 } & $\mathrm{d} 1$ & $\mathrm{~d} 7$ & $\mathrm{~d} 14$ & $\mathrm{~d} 1$ & $\mathrm{~d} 7$ & $\mathrm{~d} 14$ \\
\hline Control & $4.48 \pm 0.02^{\mathrm{cA}}$ & $4.45 \pm 0.00^{\mathrm{cA}}$ & $4.18 \pm 0.00^{\mathrm{dB}}$ & $1.23 \pm 0.28^{\mathrm{abB}}$ & $1.17 \pm 0.08^{\mathrm{nSB}}$ & $1.48 \pm 0.04^{\mathrm{aA}}$ \\
$\mathrm{A} 1$ & $4.52 \pm 0.00^{\mathrm{bcA}}$ & $4.52 \pm 0.00^{\mathrm{bA}}$ & $4.23 \pm 0.00^{\mathrm{cB}}$ & $1.29 \pm 0.00^{\mathrm{aB}}$ & $1.31 \pm 0.04^{\mathrm{nsB}}$ & $1.46 \pm 0.00^{\mathrm{abA}}$ \\
$\mathrm{A} 2$ & $4.58 \pm 0.02^{\mathrm{bB}}$ & $4.63 \pm 0.04^{\mathrm{aA}}$ & $4.28 \pm 0.00^{\mathrm{bC}}$ & $1.20 \pm 0.02^{\mathrm{bcC}}$ & $1.31 \pm 0.03^{\mathrm{nsB}}$ & $1.44 \pm 0.00^{\mathrm{abA}}$ \\
$\mathrm{A} 3$ & $4.68 \pm 0.07^{\mathrm{aA}}$ & $4.51 \pm 0.00^{\mathrm{bB}}$ & $4.37 \pm 0.00^{\mathrm{aB}}$ & $1.14 \pm 0.04^{\mathrm{cNS}}$ & $1.18 \pm 0.12^{\mathrm{nsNS}}$ & $1.27 \pm 0.21^{\mathrm{cNS}}$ \\
$\mathrm{A} 4$ & $4.56 \pm 0.01^{\mathrm{bcA}}$ & $4.55 \pm 0.00^{\mathrm{bA}}$ & $4.28 \pm 0.00^{\mathrm{bB}}$ & $1.19 \pm 0.00^{\mathrm{bcB}}$ & $1.35 \pm 0.00^{\mathrm{nSA}}$ & $1.40 \pm 0.03^{\mathrm{bA}}$ \\
\hline
\end{tabular}

${ }^{1}$ A1: with $0.010 \%$ lavender powder; A2: with $0.025 \%$ lavender powder, A3: with $0.050 \%$; A4: with $0.075 \%$ lavender powder. $\mathrm{d}$ 1, d 7 and d 14: days 1, 7 and 14 after fermentation. Values in same row and column having different superscripts differ significantly $(\mathrm{P}<0.05)$; ns, NS: not significant. Lower case letters indicate differences between samples; capital letters show differences between storage times.

\subsection{Antioxidant Activities and Total Phenolic Contents of Yoghurt Samples}

Antioxidant activities and total phenolic contents of yoghurt samples are shown in Table 2. The highest ABTS and DPPH radicals scavenging activities were determined in the A4 sample $(\mathrm{P}<0.05)$. The DPPH inhibition \% values for the control, A1, A2, A3 and A4 samples were detected as 2.82, 3.32, 3.76, 4.01 and 4.70, respectively. The TEAC values of control, A1, A2, A3 and A4 samples were determined to be 170.89, 190.87, 240.47, 284.75 and $311.01 \mu \mathrm{M}$ Trolox, respectively. The results of the ABTS and DPPH tests were consistent in terms of radical scavenging activity of each yoghurt samples. Gülçin and colleagues [14] reported that free radical scavenging activity of lavender increased depending on the ratio of lavender powder used in the formulation.

The highest total phenolic content $(0.10 \mathrm{mg}$ GAE/g) was determined in A4 sample $(\mathrm{P}<0.05)$, while there was no statistically difference in total phenolic contents of other sample groups ( $\mathrm{P}>0.05)$. The total phenolic content of lavender was $27.42 \mathrm{mg} \mathrm{GAE} / \mathrm{g}$ [32], thus the use of lavender powder at very low levels $(0.01,0.025,0.050$ and $0.075 \%)$ did not generally affect the total phenolic contents of yoghurts.

\subsection{Microbial Dynamic During Cold Storage}

The changes in microbial flora of yoghurt samples during the storage period are shown in Table 4. S. thermophilus counts were statistically stable in the control, A1, A2 and A4 samples during the storage time and the mean counts of it were defined between 8.75-8.88 log $\mathrm{CFU} / \mathrm{g}$. Do Espírito and colleagues [29] asserted that $S$. thermophilus counts remained constant for 28 days at cold storage of yoghurts containing passion fruit peel powder. On the other hand, the $S$. thermophilus counts in A3 sample containing $0.050 \%$ lavender powder increased 0.61 $\log$ unit after 14 days. It may be due to the fact that $S$. thermophilus dominated in the yoghurt flora because of the antimicrobial effect of lavender on other microorganisms [13]. 0.050\% 
lavender powder supported the growth of S. thermophilus in the yoghurt media. Higher and lower lavender powder ratios than $0.050 \%$ were not observed to have a negative effect on $S$. thermophilus counts.

The counts of L. bulgaricus in control sample decreased at the end of the storage time. Do Espírito and colleagues [29] and Shori [33] determined a decrease in L. bulgaricus counts of control yoghurt samples at the end of the storage time. In A1, A2 and A4 samples, the mean L. bulgaricus counts were found to be $8.38,8.35$ and $8.40 \log \mathrm{CFU} / \mathrm{g}$, respectively and no statistically change was observed in its counts during the storage period. Compared to the control, lavender powder was found to support growth of lactobacilli. Marhamatizadeh and colleagues [34] reported that dried lavender increased the number of lactobacilli such as $L$. acidophilus, L. casei and L. paracasei. The decrease in the number of L. bulgaricus on the 14th day of storage in A3 sample may be due to increase in $S$. thermophilus counts.

Table 4. Changes in microbial flora of yoghurt samples during the storage period (log CFU/g).

\begin{tabular}{|c|c|c|c|c|}
\hline Yoghurt bacteria & Samples $^{1}$ & $\mathrm{~d} 1$ & $\mathrm{~d} 7$ & d 14 \\
\hline \multirow{5}{*}{ S. thermophilus } & Control & $8.89 \pm 0.21^{\mathrm{nsNS}}$ & $8.61 \pm 0.08^{\mathrm{nsNS}}$ & $9.08 \pm 0.30^{\text {nsNS }}$ \\
\hline & A1 & $8.71 \pm 0.09^{\mathrm{nsNS}}$ & $8.67 \pm 0.08^{\mathrm{nsNS}}$ & $8.86 \pm 0.21^{\mathrm{nsNS}}$ \\
\hline & A2 & $8.77 \pm 0.13^{\mathrm{nsNS}}$ & $8.82 \pm 0.12^{\mathrm{nsNS}}$ & $9.05 \pm 0.30^{\mathrm{nsNS}}$ \\
\hline & A3 & $8.66 \pm 0.04^{\mathrm{nsB}}$ & $8.63 \pm 0.01^{\mathrm{nsB}}$ & $9.24 \pm 0.19^{\mathrm{nsA}}$ \\
\hline & A4 & $8.91 \pm 0.13^{\mathrm{nsNS}}$ & $8.72 \pm 0.11^{\mathrm{nsNS}}$ & $8.86 \pm 0.02^{\mathrm{nsNS}}$ \\
\hline \multirow{5}{*}{ L. bulgaricus } & Control & $8.58 \pm 0.06^{\mathrm{nsAB}}$ & $8.78 \pm 0.09^{\mathrm{aA}}$ & $8.36 \pm 0.13^{\mathrm{aB}}$ \\
\hline & A1 & $8.43 \pm 0.26^{\mathrm{nsNS}}$ & $8.46 \pm 0.17^{\mathrm{abNS}}$ & $8.26 \pm 0.01^{\mathrm{abNS}}$ \\
\hline & A2 & $8.34 \pm 0.26^{\mathrm{nsNS}}$ & $8.50 \pm 0.19^{\mathrm{abNS}}$ & $8.22 \pm 0.01^{\mathrm{abNS}}$ \\
\hline & A3 & $8.02 \pm 0.02^{\mathrm{nsB}}$ & $8.19 \pm 0.04^{\mathrm{bA}}$ & $8.01 \pm 0.04^{\mathrm{bB}}$ \\
\hline & A4 & $8.53 \pm 0.34^{\mathrm{nsNS}}$ & $8.45 \pm 0.04^{\mathrm{abNS}}$ & $8.24 \pm 0.00^{\mathrm{abNS}}$ \\
\hline \multirow{5}{*}{ Total bacteria } & Control & $8.60 \pm 0.00^{\mathrm{nsA}}$ & $8.54 \pm 0.23^{\mathrm{nsA}}$ & $8.03 \pm 0.01^{\mathrm{cB}}$ \\
\hline & A1 & $8.29 \pm 0.04^{\mathrm{nsNS}}$ & $8.21 \pm 0.01^{\mathrm{nsNS}}$ & $8.20 \pm 0.02^{\mathrm{bNS}}$ \\
\hline & A2 & $8.30 \pm 0.04^{\mathrm{nsNS}}$ & $8.30 \pm 0.04^{\mathrm{nsNS}}$ & $8.24 \pm 0.05^{\mathrm{bNS}}$ \\
\hline & A3 & $7.97 \pm 0.04^{\mathrm{nsNS}}$ & $8.13 \pm 0.16^{\mathrm{nsNS}}$ & $8.25 \pm 0.02^{\mathrm{bNS}}$ \\
\hline & A4 & $7.72 \pm 0.59^{\mathrm{nsNS}}$ & $8.17 \pm 0.09^{\mathrm{nsNS}}$ & $8.31 \pm 0.01^{\mathrm{aNS}}$ \\
\hline
\end{tabular}

${ }^{1}$ A1: with $0.010 \%$ lavender powder; A2: with $0.025 \%$ lavender powder; A3: with $0.050 \%$; A4: with $0.075 \%$ lavender powder.d 1, d 7 and d 14: days 1, 7 and 14 after fermentation. Different letters in the same row and column indicate significantly different $(\mathrm{P}<0.05)$. ns, NS: not significant. Lower case letters indicate differences between samples; capital letters show differences between storage times.

No yeast and fungi were observed in all yoghurt samples during the storage time. The total bacteria count was statistically reduced in the control sample at the end of the storage $(\mathrm{P}<0.05)$, while it remained constant in other yoghurt samples containing lavender powder during the storage time. On the 14th day of the storage time, statistical differences were detected between the total bacterial counts of the yoghurt samples and the lowest total bacterial count was determined in control sample $(\mathrm{P}<0.05)$. This difference may be due to the positive effect of lavender powder on the growth of S. thermophilus and L. bulgaricus.

\subsection{Sensorial Characteristics of Yoghurt Samples}

Sensorial characteristics of yoghurt samples are shown in Figure 2. The best appearance score (5.88) was determined in A1 sample according to the sensory acceptability test $(\mathrm{P}<0.05)$. The appearance score of A2, A3 and A4 samples decreased with the use of lavender powder at higher ratios. The highest texture score (5.44) was detected in A1 sample $(\mathrm{P}<0.05)$, generally, the texture scores of yoghurts added with lavender powder were found higher than the control. Acidity scores were higher in A3 and A4 than control $(\mathrm{P}<0.05)$, it may have been caused by supporting effect of the higher amounts of lavender powder on acidic taste. 


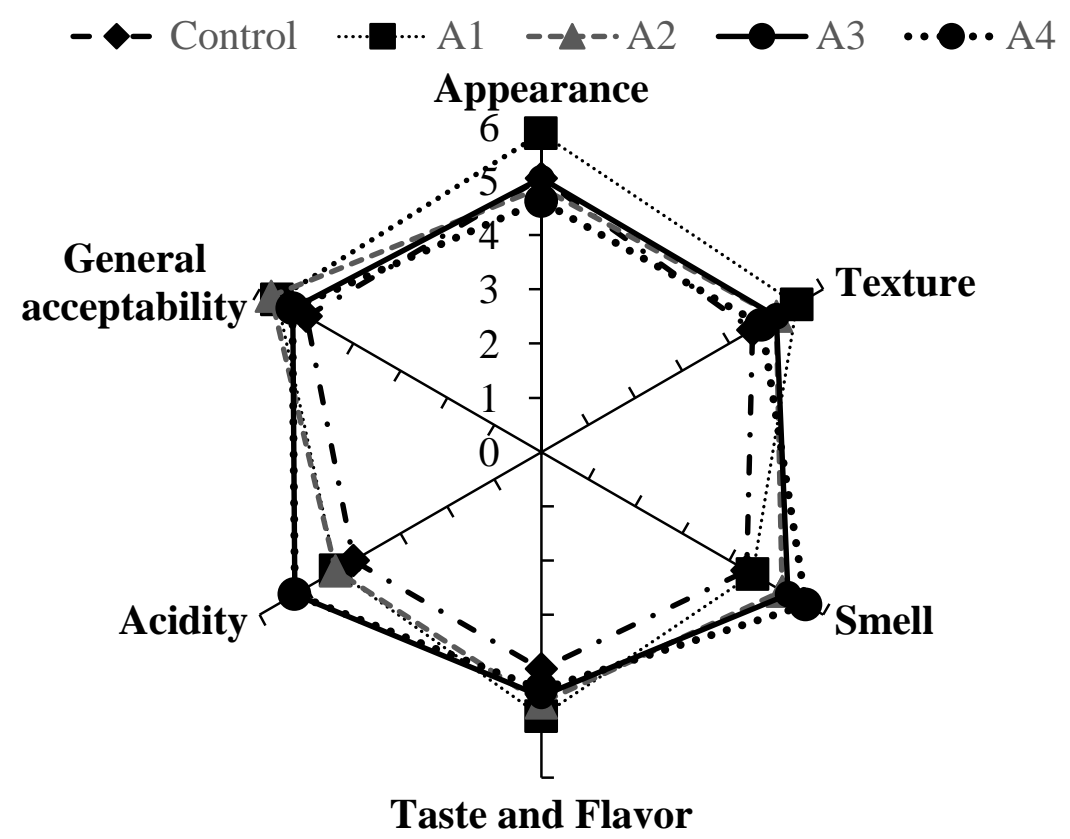

Figure 2. Sensorial characteristics of yoghurt samples (on day 7)

The highest smell score was determined in A4 sample, the smell score increased depending on the amount of lavender powder. However, the difference between smell scores of A1 and the control samples was statistically insignificant. The highest taste and flavor score was determined in A1 sample, taste and flavor scores decreased with the use of lavender powder at higher ratios. The highest general acceptability score was determined in the A1 and A2 samples. According to general acceptability score, A1 and A2 were the most preferred yoghurt samples for consumers.

\section{CONCLUSION}

In this study, the effect of lavender powder on lactic acid bacteria was determined. The results showed that the lactic acid production during the fermentation and the viability of $S$. thermophilus and L. bulgaricus during the cold storage can be enhanced by supplementation of lavender powder. It was determined that the antioxidant activity of yoghurt increased with the addition of lavender powder. The antioxidant activity of yoghurt increased about 2-fold by addition of $0.075 \%$ lavender powder. Considering the scores of sensory properties and functional properties of lavender powder, it can be thought to be a good supplement for yoghurt.

\section{Acknowledgement}

This paper was presented as an oral presentation at the I. International Congress on Medicinal and Aromatic Plants (Konya, Turkey, May 10-12, 2017).

\section{Conflict of Interests}

Authors declare that there is no conflict of interests.

\section{REFERENCES}

[1]. Akın, N. (2006). Modern yoghurt science and technology. Konya: Selcuk University Agriculture Faculty Food Engineering Department Press.

[2]. Gahruie, H. H., Eskandari, M. H., Mesbahi, G., \& Hanifpour, M. A. (2015). Scientific and technical aspects of yogurt fortification: A review. Food Science and Human Wellness, $4(1), 1-8$. 
[3]. Park, Y. S., Kim, Y. S., \& Shin, D. H. (2003). Changes in physicochemical characteristics and microbial populations during storage of lactic acid bacterial fermented vegetable yogurt. Food Science and Biotechnology, 12(6), 654-658.

[4]. Kiros, E., Seifu, E., Bultosa, G., \& Solomon, W. (2016). Effect of carrot juice and stabilizer on the physicochemical and microbiological properties of yoghurt. LWT-Food Science and Technology, 69, 191-196.

[5]. Singh, G., \& Muthukumarappan, K. (2008). Influence of calcium fortification on sensory, physical and rheological characteristics of fruit yogurt. LWT-Food Science and Technology, 41(7), 1145-1152.

[6]. Kailasapathy, K., Harmstorf, I., \& Phillips, M. (2008). Survival of Lactobacillus acidophilus and Bifidobacterium animalis ssp. lactis in stirred fruit yogurts. LWT-Food Science and Technology, 41(7), 1317-1322.

[7]. Tomic, N., Dojnov, B., Miocinovic, J., Tomasevic, I., Smigic, N., Djekic, I., et al. (2017). Enrichment of yoghurt with insoluble dietary fiber from triticale-A sensory perspective. LWT-Food Science and Technology, 80, 59-66.

[8]. Staffolo, M. D., Bertola, N., \& Martino, M. (2004). Influence of dietary fiber addition on sensory and rheological properties of yogurt. International Dairy Journal, 14(3), 263-268.

[9]. Chouchouli, V., Kalogeropoulos, N., Konteles, S. J., Karvela, E., Makris, D. P., \& Karathanos, V. T. (2013). Fortification of yoghurts with grape (Vitis vinifera) seed extracts. LWT-Food Science and Technology, 53(2), 522-529.

[10]. Halah, M., \& Mehanna, N. S. (2011). Use of natural plant antioxidant and probiotic in the production of novel yogurt. Journal of Evolutionary Biology Research, 3(2), 12-18.

[11]. Amirdivani, S. (2007). Inclusion of Mentha piperita, Anethum graveolence and Ocimum basilicum in yogurt and their effect on the inhibition of enzyme relevant to hypertension and type-2 diabetes. Unpublished master's thesis, University of Malaya, Malaya, Kuala Lumpur.

[12]. Upson, T. (2002). The taxonomy of the genus Lavandula L. In M. Lis-Balchin (Ed.), Lavender: The genus Lavandula (1st ed., pp. 2-34). London: Taylor \& Francis.

[13]. Cavanagh, H., \& Wilkinson, J. (2002). Biological activities of lavender essential oil. Phytotherapy Research, 16(4), 301-308.

[14]. Gülçin, İ., Şat, İ. G., Beydemir, Ş., Elmastaş, M., \& Küfrevioğlu, Ö. İ. (2004). Comparison of antioxidant activity of clove (Eugenia caryophylata Thunb) buds and lavender (Lavandula stoechas L.). Food Chemistry, 87(3), 393-400.

[15]. Spiridon, I., Colceru, S., Anghel, N., Teaca, C. A., Bodirlau, R., \& Armatu, A. (2011). Antioxidant capacity and total phenolic contents of oregano (Origanum vulgare), lavender (Lavandula angustifolia) and lemon balm (Melissa officinalis) from Romania. Natural Product Research, 25(17), 1657-1661.

[16]. Standard, B. (1955). Gerber method for the determination of fat in milk and milk products (BS696). London: British Standard Institution.

[17]. Guzmán-González, M., Morais, F., Ramos, M., \& Amigo, L. (1999). Influence of skimmed milk concentrate replacement by dry dairy products in a low fat set-type yoghurt model system. I: Use of whey protein concentrates, milk protein concentrates and skimmed milk powder. Journal of the Science of Food and Agriculture, 79(8), 1117-1122.

[18]. Amatayakul, T., Halmos, A., Sherkat, F., \& Shah, N. (2006). Physical characteristics of yoghurts made using exopolysaccharide-producing starter cultures and varying casein to whey protein ratios. International Dairy Journal, 16(1), 40-51. 
[19]. Francis, F. J. (1998). Color analysis. In S. S. Nielsen (Ed.), Food analysis (2nd ed., pp. 559-612). Gaithersburg: Aspen Publishers.

[20]. Richardson, G. (1985). Standard methods of the examination of dairy products (15th ed.). Washington, DC: American Public Health Association.

[21]. Re, R., Pellegrini, N., Proteggente, A., Pannala, A., Yang, M., \& Rice-Evans, C. (1999). Antioxidant activity applying an improved ABTS radical cation decolorization assay. Free Radical Biology and Medicine, 26(9), 1231-1237.

[22]. Brand-Williams, W., Cuvelier, M.-E., \& Berset, C. (1995). Use of a free radical method to evaluate antioxidant activity. LWT-Food Science and Technology, 28(1), 25-30.

[23]. McCue, P. P., \& Shetty, K. (2005). Phenolic antioxidant mobilization during yogurt production from soymilk using Kefir cultures. Process Biochemistry, 40(5), 1791-1797.

[24]. Kodaka, H., Mizuochi, S., Teramura, H., \& Nirazuka, T. (2005). Comparison of the compact dry TC method with the standard pour plate method (AOAC Official Method 966.23) for determining aerobic colony counts in food samples: performance-tested method $^{\mathrm{SM}}$. Journal of AOAC International, 88(6), 1702-1713.

[25]. Van de Casteele, S., Vanheuverzwijn, T., Ruyssen, T., Van Assche, P., Swings, J., \& Huys, G. (2006). Evaluation of culture media for selective enumeration of probiotic strains of lactobacilli and bifidobacteria in combination with yoghurt or cheese starters. International Dairy Journal, 16(12), 1470-1476.

[26]. Luana, N., Rossana, C., Curiel, J. A., Kaisa, P., Marco, G., \& Rizzello, C. G. (2014). Manufacture and characterization of a yogurt-like beverage made with oat flakes fermented by selected lactic acid bacteria. International Journal of Food Microbiology, $185,17-26$.

[27]. Cruz, A. G., Cadena, R. S., Walter, E. H., Mortazavian, A. M., Granato, D., Faria, J. A., et al. (2010). Sensory analysis: relevance for prebiotic, probiotic, and synbiotic product development. Comprehensive Reviews in Food Science and Food Safety, 9(4), 358-373.

[28]. Minitab, C. (1991). Minitab reference manual (Release 7.1). State Coll., PA16801, USA.

[29]. Do Espírito Santo, A., Perego, P., Converti, A., \& Oliveira, M. (2012). Influence of milk type and addition of passion fruit peel powder on fermentation kinetics, texture profile and bacterial viability in probiotic yoghurts. LWT-Food Science and Technology, 47(2), 393-399.

[30]. De Martino, L., De Feo, V., \& Nazzaro, F. (2009). Chemical composition and in vitro antimicrobial and mutagenic activities of seven Lamiaceae essential oils. Molecules, 14(10), 4213-4230.

[31]. Bonczar, G., Wszołek, M., \& Siuta, A. (2002). The effects of certain factors on the properties of yoghurt made from ewe's milk. Food Chemistry, 79(1), 85-91.

[32]. Dudonné, S., Vitrac, X., Coutiere, P., Woillez, M., \& Mérillon, J.-M. (2009). Comparative study of antioxidant properties and total phenolic content of 30 plant extracts of industrial interest using DPPH, ABTS, FRAP, SOD, and ORAC assays. Journal of Agricultural and Food Chemistry, 57(5), 1768-1774.

[33]. Shori, A. B. (2013). Antioxidant activity and viability of lactic acid bacteria in soybeanyogurt made from cow and camel milk. Journal of Taibah University for Science, 7(4), 202-208.

[34]. Marhamatizadeh, M. H., Mahmoudipour, H., \& Ehsandoost, E. (2014). Influence of addition of lavender (Lavandula officinalis L.) on the growth, acidification profile and viable counts of different probiotics in fermented milk and yoghurt during fermentation and refrigerated storage. BioTechnology: An Indian Journal, 9(8), 335-345. 